\title{
Novel Charlotte Karya David Foenkinos : Sebuah Narasi Tentang Diskriminasi, Rasisme, dan Holocaust
}

\author{
Tania Intan \\ Universitas Padjajaran \\ tania.intan@unpad.ac.id
}

\begin{abstract}
Abstrak
Nazi yang berkuasa sejak tahun 1933 tidak merahasiakan ketidaksukaannya pada kaum Yahudi. Adolf Hitler bahkan mendeklarasikan bahwa "Antisemitisme rasional harus mengarah pada sistem oposisi legal, yang tujuan akhirnya untuk menghapus seluruh orang Yahudi”. Ia juga mengembangkan ide bahwa Yahudi merupakan ras jahat yang mendominasi dunia. Anti-semitisme Nazi ditanamkan dalam situasi keagamaan dan dalam konteks politik. Kemudian, Nazi menambahkan sebuah dimensi lebih lanjut, yaitu anti-semitisme rasial. Dengan logika bahwa Yahudi bukanlah komunitas keagamaan melainkan rasial, Nazi pun melancarkan berbagai agresi berupa tindakan diskriminatif, rasis, hingga Holocaust. Fenomena kelam dalam sejarah manusia ini pun terungkap di dalam novel Charlotte karya David Foenkinos, seorang penulis Prancis yang kerap menerima penghargaan sastra. Pembahasan akan dilakukan dengan metode analisis deskriptif melalui pendekatan struktural yang meliputi pengkajian aspek tokoh, latar, dan sudut pandang.
\end{abstract}

Kata Kunci : Diskriminasi, Rasisme, Holocaust, Charlotte

\begin{abstract}
The Nazi ruling since 1933 made no secret of his dislike of Jews. Adolf Hitler even declared that "rational antisemitism must lead to a system of legal opposition, the ultimate goal of wiping out all Jews". He also developed the idea that Jews were the evil race that dominated the world. Nazi anti-Semitism was instilled in religious situations and in political context. Then, the Nazis added a further dimension, racial anti-semitism. With the logic that Jews werere not religious but racial communities, the Nazis launched various aggressions in the form of discriminatory, racist, and Holocaust. This dark phenomenon in human history is revealed in Charlotte's novel by David Foenkinos, a French writer who often receives literary awards. The discussion will be conducted by descriptive analysis method through structural approach which includes assessment of character, background, and point of view.
\end{abstract}

Key Words : Discrimination, Racism, Holocaust, Charlotte

\section{Pendahuluan}

Memperlakukan seseorang atau suatu kelompok secara tidak adil karena perbedaan agama, suku, ras, merupakan tindakan dasar diskriminasi. Theodorson \& Theodorson (1979:115-116) menjelaskan diskriminasi sebagai perlakuan tidak seimbang terhadap perseorangan atau kelompok berdasarkan sesuatu, biasanya kategorikal atau dengan atribut- atribut khas seperti ras, kesukubangsaan, agama, atau keanggotaan kelas-kelas sosial. Diskriminasi dapat terjadi secara langsung yaitu ketika hukum, peraturan, atau kebijakan, jelas-jelas menyebutkan karakteristik tertentu seperti jenis kelamin, ras, dan sebagainya serta menghambat adanya peluang yang sama. Diskriminasi juga dapat terjadi secara tidak langsung, ketika peraturan bersifat netral menjadi diskriminatif saat diterapkan di lapangan. 
Ada beberapa macam diskriminasi yang terjadi di lingkungan masyarakat: diskriminasi terhadap suku bangsa, ras, dan gender; diskriminasi terhadap agama dan keyakinan; diskriminasi terhadap ideologi dan politik serta diskriminasi terhadap adat dan kesopanan.

Dalam sejarah peradaban manusia, salah satu diskriminasi terberat yang pernah terjadi adalah diskriminasi yang dilakukan oleh Partai Nazi terhadap kaum Yahudi. Nazi percaya bahwa bangsa Arya, suku asli bangsa Jerman, merupakan ras yang superior, sementara Yahudi merupakan ras yang rendah, harus dikucilkan, atau bahkan dimusnahkan dari permukaan bumi. Diskriminasi ras ini terjadi sekitar tahun 1933-1945. Pada masa kekuasaannya, Nazi yang dipimpin oleh Adolf Hitler giat menyerukan propaganda anti-Yahudi dan pembersihan kaum tersebut dari wilayah Jerman khususnya, dan dari benua Eropa pada umumnya. Pemboikotan serta penghancuran sinagoge dan toko-toko milik Yahudi menjadi aksi nyata kebencian mereka. Pada masa itu, kaum Yahudi berjumlah sekitar sembilan juta orang. Nazi pun membuat kemah-kemah pengasingan bagi orang-orang Yahudi yang dipaksa untuk bekerja dan tidak sedikit yang tewas menyedihkan. Mulai tahun 1941 sampai 1944, Nazi mendeportasi jutaan orang Yahudi ke tempat pembantaian. Peristiwa tersebut dikenal dengan sebutan Holocaust.

Diskriminasi dan pembantaian terhadap kaum Yahudi ini menjadi tema yang terus hidup dan tetap diperbincangkan oleh masyarakat hingga saat ini terutama di Eropa. Tema tersebut juga telah banyak digunakan dalam karya sastra Prancis, salah satunya dalam novel Charlotte karya David Foenkinos, yang dipublikasikan pada tahun 2014 di Paris oleh Folio dengan jumlah halaman 253. Novel ini mendapatkan dua penghargaan, yaitu Prix Goncourt des Lycéens dan Prix Renaudot pada tahun yang sama ketika diterbitkan. David Foenkinos terinspirasi dari kisah nyata seorang pelukis perempuan Yahudi bernama Charlotte Salomon.

David Foenkinos adalah seorang penulis Prancis yang lahir di Paris pada tanggal 28 Oktober 1974. Ketika muda, ia memiliki ketertarikan yang besar terhadap dunia sastra dan jazz. Ia menyelesaikan studi sastranya di Universitas La Sorbonne, namun mengawali karirnya sebagai guru musik. Di awal karir kepenulisannya pada tahun 2002, David Foenkinos melahirkan sebuah karya yang berjudul Inversion de l'Idiote. Novel tersebut disambut dengan kritikan pedas tetapi berhasil meraih penghargaan Prix Francois-Mauriac. Pada tahun 2004 David Foenkinos berhasil mengukuhkan namanya sebagai seorang penulis besar dengan karyanya yang berjudul La Parution du Potentiel Erotique de Ma Femme yang terjual hingga 100.000 salinan dan mendapat Prix Roger-Nimier.

Untuk mengungkapkan narasi tentang diskriminasi, rasisme, dan Holocaust yang dialami tokoh utama, Charlotte, dalam novel ini, maka diperlukan teori yang tepat untuk menjawab permasalahan yang dianalisis. Metode analisis deskriptif dengan pendekatan struktural digunakan dengan analisis struktural sastra khususnya mengenai tokoh, latar, dan sudut pandang. Menurut Hamon (1991:23), deskripsi adalah sebuah wacana yang menunjukkan sesuatu yang di- 
jelaskan yang tampak menjadi sorotan. Pendekatan ini akan mengondisikan sebuah karya sastra secara objektif, yaitu hanya melihat objek material yang terdapat dalam karya sastra tersebut, seperti yang diungkapkan oleh Barthes (1991: 214).

\section{Nazi, Diskriminasi, Rasisme, dan Holo- caust}

Nazi menggambarkan Yahudi sebagai ras dan bukan sebuah kelompok keagamaan. Menurut mereka, antisemitisme ini bisa diselesaikan oleh kemah konsentrasi. Dengan demikian, logika anti-semitisme rasial Nazi mengarah pada penghancuran kaum tersebut. Ketika Hitler mulai berkuasa pada tanggal 30 Januari 1933 sebagai kepala koalisi pemerintahan, sasaran utamanya adalah membentuk konsolidasi kekuatan dan menghapus oposisi politik. Penyerangan terhadap kaum Yahudi dimulai pada tanggal 1 April 1933 dengan pemboikotan bisnis mereka. Satu minggu kemudian, Nazi memberhentikan Yahudi dari pelayanan sipil dan di akhir bulan, sekolah-sekolah di Jerman diperketat dengan pembatasan kuota. Pada tanggal 10 Mei 1933, ribuan pelajar Nazi bersama para pengajarnya menyerang 30 kota di seluruh Jerman untuk menghancurkan buku-buku yang ditulis oleh non-Arya dan mereka yang menentang ideologi Nazi. Buku-buku tersebut dibakar sebagai usaha untuk membersihkan budaya Jerman dari "un-germanic".

Ketika sentimen diskriminasi terhadap Yahudi semakin meningkat, hukum Jerman membutuhkan sebuah definisi legal dari orang
Yahudi dan orang Arya. Oleh karena itu, disebarluaskanlah pada rapat umum tahunan Nazi di Nürnberg pada tanggal 15 September 1935, Hukum Nürnberg, yaitu hukum untuk perlindungan darah Jerman dan kehormatan Jerman dan Hukum Penduduk Reich, yang menjadi inti dari legalisasi gerakan anti-Yahudi dan pengendalian dan pengawasan terhadap kaum Yahudi di seluruh tanah Jerman. Pernikahan dan hubungan seksual antara orang Yahudi dan warga dari "Jerman atau darah kerabat" dilarang. Hanya bangsa asli Jerman yang berhak untuk mendapatkan pelayanan sipil dan negara. Hukum Nürnberg secara formal membagi orang-orang Jerman dan Yahudi, meskipun kedua kata tersebut tidak didefinisikan. Dua kategori dasar yang disusun pada bulan November 1935: Yahudi, yaitu mereka dengan paling sedikit tiga kakek, dan Mischlinge (suku campuran), orang dengan satu atau dua kakek. Definisi dari kata Yahudi pada pokoknya tidak berdasarkan pada identitas atau pernyataan pribadi atau agama yang mereka yakini, tetapi pada leluhurnya. Penggolongan ini adalah tahap awal dari tindakan pemusnahan kaum Yahudi selanjutnya.

Seperti yang dijelaskan oleh George M Fredrickson (2002: 1) dalam Racism: a Short Story, istilah 'rasisme' sering digunakan sebagai cara bebas dan tidak reflektif untuk menggambarkan perasaan negatif dari satu grup etnis atau "orang" terhadap yang lainnya, juga sebagai reaksi dari sebuah sikap. Akan tetapi, kebencian dari sebuah kelompok terhadap kelompok lainnya terkadang diekspresikan dan dilakukan berdasarkan pemikiran tunggal dan secara brutal, sehingga melampaui prasangka dan keangkuhan. Hitler 
mengarahkan teori-teori rasis pada aksi genosidanya terhadap Yahudi di Eropa, seperti juga dominasi orang kulit putih di Amerika Selatan yang menjelaskan alasan hukum Jim Crow diperlukan untuk membuat orang kulit putih dan orang kulit hitam terpisah dan tidak sama derajatnya.

Kata 'rasis' sendiri pertama kali muncul pada tahun 1930 yang digunakan untuk mengungkapkan penganiayaan-penganiayaan terhadap Yahudi oleh Nazi. Kata tersebut menjelaskan perbedaan etnis yang mengakar dengan kuat pada bahasa, adat, dan kekerabatan yang dikesampingkan, atas nama pengelompokan pigmentasi, seperti dominasi kulit putih atau bangsa Arya. Oleh karena itu, terminologi rasisme melebihi teori tentang penggolongan manusia atau pemikiran buruk terhadap sebuah kelompok yang tidak memiliki kendali. Dalam rasisme, dibenarkan untuk membentuk suatu golongan ras, hierarki yang diyakini mencerminkan hukum alam atau ketetapan Tuhan. Meskipun sudah umum digunakan, 'rasisme' menjadi sebuah istilah yang ambigu. Rasisme dapat diartikan sebagai ketidakpekaan terhadap diskriminasi di masa lalu dan terhadap kelompok yang dikategorikan secara rasial. Rasisme merupakan sebuah pernyataan kuat untuk menjelaskan beberapa tindakan brutal dan tidak adil sesuai dengan konsep ras pada masa Jim Crow, Nazi, dan Apartheid. Ketiga contoh ini menarik perhatian para ahli sejarah pada fakta bahwa Yahudi dan orang kulit hitam sudah menjadi korban untuk direndahkan dan diperlakukan secara kejam karena karakteristik fisik, keturunan, dan kondisi spiritual mereka.

Pada tingkat selanjutnya, Holocaust pun terjadi. Secara umum, Holocaust merupakan persekusi dan pembantaian sekitar enam juta orang Yahudi yang dilakukan secara sistematis, birokratis, dan disponsori oleh rezim Nazi beserta para kolaboratornya. 'Holocaust' berasal dari bahasa Yunani yang artinya "berkorban dengan api." Nazi meyakini bahwa bangsa Jerman adalah "ras unggul" sedangkan kaum Yahudi dianggap "inferior," yaitu ancaman luar terhadap apa yang disebut dengan masyarakat rasial Jerman. Selain melakukan pembersihan etnis kaum Yahudi, Nazi juga menjadikan kelompok-kelompok lain yang dianggap memiliki "ras rendahan" sebagai target, yang terdiri atas: orang Gipsi, penyandang cacat, dan sebagian bangsa Slavia (Polandia, Rusia, dan yang lainnya). Kelompok lainnya juga dipersekusi karena alasan politis, ideologis, dan perilaku, di antaranya kaum Komunis, Sosialis, Kesaksian Yehova serta kaum homoseksual.

\section{Kehidupan Charlotte, Sang Tokoh Utama}

Novel Charlotte menceritakan kisah hidup seorang pelukis perempuan Yahudi bernama Charlotte Salomon. Berlin merupakan latar tempat pertama di mana cerita ini dimulai. Kota tersebut sangat penting keberadaannya karena merupakan titik pusat bagi kehidupan kaum Yahudi di Jerman. Sepertiga dari kaum Yahudi di Jerman bertempat tinggal di Berlin. Selain sebagai ibu kota Jerman, kota ini merupakan sentrum bagi perencanaan politik Nazi setelah Adolf Hitler mulai berkuasa pada tanggal 30 Januari 1933. Di kota inilah, Charlotte lahir dalam keluarga Yahudi di 
wilayah Charlottenburg.

Kehidupan Charlotte selanjutnya dikelilingi oleh peristiwa-peristiwa tragis yang menimpa keluarganya. 'Charlotte' adalah nama yang diberikan oleh Fransziska, ibunya, untuk mengenang saudara perempuannya yang telah meninggal karena bunuh diri di usia sepuluh tahun. Ketika Charlotte berumur delapan tahun, kondisi kejiwaan ibunya pun memburuk dan selalu berupaya untuk mengakhiri hidup, seperti yang dulu dilakukan saudara perempuannya. Fransziska telah dua kali mencoba bunuh diri. Yang pertama, ia diselamatkan oleh suaminya ketika tengah menelan seluruh isi botol opium. Yang kedua, ia berhasil melakukan bunuh diri dengan cara melompat dari jendela kamarnya. Nenek Charlotte pun menemukan jasad putrinya itu telah berlumuran darah. Charlotte kecil menghabiskan masa kanak-kanaknya dalam kebohongan tentang kematian ibunya. Tak ada yang memberitahunya bahwa Fransziska meninggal karena bunuh diri.

Sementara itu, di luar sana, ketika Nazi menjadi satu-satunya partai politik resmi di Jerman, Hitler mulai menyebarkan ideologi antiYahudinya dan melahirkan undang-undang Nürnberg yang menimbulkan penderitaan bagi kaum Yahudi. Sebagian dari populasi kaum ini mulai bermigrasi untuk menghindari penindasan dan kekerasan yang semakin meningkat.

Kata Yahudi awalnya hanya memiliki sedikit arti dalam hidup Charlotte. Masa kanakkanaknya dilalui dengan ketiadaan paham dan tradisi Yahudi pada umumnya. Orang tuanya menjalani kehidupan sekuler dan ibunya me- nyukai lagu-lagu kristiani. Selain itu, kondisi fisik Charlotte juga tidak terlihat seperti seorang gadis Yahudi. Rambut coklatnya terang, demikian pula warna matanya. Ia justru lebih terlihat seperti orang Arya.

Selain memiliki wajah yang cantik, terungkap juga karakternya yang melankolis, tertutup, dan gemar membaca. Di usia remajanya, Charlotte sempat mengalami ketidakstabilan mental. Ia menjadi sosok yang brutal dan menggebu-gebu. Ayahnya lalu mempekerjakan seorang pengasuh namun Charlotte melakukan segala cara untuk menyusahkannya. Dia membenci siapa pun yang mencoba untuk merawatnya. Dapat disimpulkan bahwa pada masa kanak-kanaknya, Charlotte memiliki sikap yang buruk dan membangkang. Ia bahkan membenci siapa pun yang mencoba bersikap baik padanya, terutama semenjak ayahnya mempekerjakan pengasuh untuk menjaga dirinya. Namun demikian, di balik sikapnya yang tidak stabil ini, Charlotte adalah anak yang pintar. Ia menjalani pendidikannya dengan serius. Sejak kecil, ia membaca buku-buku filsafat. Kegemarannya tersebut membuat Charlotte menjadi anak yang kritis terhadap keadaan sekitar yang bahkan orang dewasa pun tidak sadari.

Pada masa remaja dan dewasanya Charlotte menjadi pelukis. Ia mulai mendalami seni lukis ketika Nazi mengambil alih Jerman. Kala itu, Charlotte menjadikan seni lukis sebagai pelarian dari ketakutannya pada situasi negaranya yang terus memburuk akibat teror yang dilakukan oleh Nazi terhadap orang-orang Yahudi.

Ayah Charlotte, Albert, selalu disibukkan oleh penelitian medisnya sehingga membuat pu- 
trinya kesepian dan menghabiskan banyak waktu di tempat kakek dan neneknya. Pada tahun 1930, Albert menikahi seorang penyanyi terkenal bernama Paula Ludwig setelah mengenalkannya pada Charlotte. Pada tahun 1933, teror Nazi terhadap orang-orang Yahudi dimulai. Paula pun tidak dapat lagi menggelar konser di tempat-tempat umum. "Pria-pria berteriak histeris dan menghina. Mereka menyuruh Paula untuk pulang ke rumahnya. Mereka tidak ingin lagi mendengarnya di sini (hal. 61)." Hal ini mengindikasikan bentuk diskriminasi masyarakat yang terprovokasi propaganda Nazi terhadap kaum Yahudi. Kaum anti-semit membubarkan konser Paula secara brutal karena identitas wanita itu sebagai seorang Yahudi. Padahal sebelumnya, Paula adalah seorang penyanyi terkenal yang banyak dielu-elukan. Akibat pembubaran paksa tersebut, ia tidak pernah lagi menggelar konser secara terbuka di ruang publik. Pada kenyataannya, diskriminasi pada kaum Yahudi di Jerman dimulai sejak pengangkatan Adolf Hitler sebagai konselir Jerman. Sejak saat itulah, banyak aksi yang dilakukan oleh para anti -semit untuk menunjukkan kebencian mereka secara terbuka terhadap kaum Yahudi.

Kemudian kakek dan neneknya pun memutuskan untuk membawa Charlotte pergi ke Italia dan sejak itu Charlotte semakin mendalami dunia seni lukis. Ketika kembali ke Jerman, keadaan semakin memburuk. Nenek dan kakek Charlotte lalu memutuskan untuk meninggalkan Jerman dan tinggal di vila l'Ermitage di Villefranche-sur Mer, Prancis, milik Ottile Moore, seorang perempuan Amerika yang mereka kenal ketika berada di Spanyol. Sementara itu, Charlotte tetap tinggal di Berlin bersama ayahnya dan Paula untuk melanjutkan sekolahnya. Ayahnya mengusulkan kepada Charlotte untuk melanjutkan pendidikannya ke sekolah desain sehingga ia bisa mengasah bakat seni lukisnya. Keinginan Charlotte untuk melanjutkan pendidikannya ke Akademi Seni di Berlin sangat besar. Akan tetapi karena latar belakangnya, tidak mudah baginya untuk bisa lolos. Akademi itu hanya menerima sedikit orang-orang Yahudi, hanya sekitar 1\% (hal. 70). Pembatasan tersebut berlaku terutama pada sekolah-sekolah umum, sementara di sekolah-sekolah kejuruan masih terdapat sedikit toleransi bagi para pelajar Yahudi. "Itu terlalu berisiko.", katanya. "Mengapa itu beresiko?" Bartning geram. Dia bisa menjadi ancaman untuk para pemuda Arya. Gadis Yahudi adalah penggoda, menjijikkan (hal. 73). “

Orang-orang Yahudi memang dianggap berbahaya keberadaannya dalam komunitas masyarakat Jerman. Para perempuan Yahudi juga memiliki citra buruk, dianggap sebagai perempuan murahan, sehingga dapat mengancam kehormatan dan kemurnian darah para pemuda Arya. Namun hal itu dianggap tidak logis oleh salah satu guru Charlotte yang bernama Ludwig Bartning yang kemudian membantunya untuk diterima di Akademi tersebut. Charlotte pun berhasil lolos setelah sang guru meyakinkan bakatnya kepada para pimpinan Akademi dengan diiringi pandangan yang tidak menyenangkan.

Di usianya yang ke dua puluh satu, Charlotte menyukai guru vokal ibu tirinya, Alfred Wolfshon. Alfred memang bukan pria dengan ru- 
pa yang tampan, tapi keberadaannya selalu berhasil menarik perhatian orang-orang di sekitar. Ia pria yang bertalenta dan kepribadiannya menyenangkan. Alfred mengagumi lukisan-lukisan Charlotte. Tak jarang Alfred pun mengunjungi Charlotte di kamarnya untuk melihat gambargambarnya atau hanya sekadar mengobrol. Tanpa sepengetahuan ayahnya dan Paula, Charlotte dan Alfred sering bertemu di sebuah kafe. Suatu hari mereka memutuskan untuk menghabiskan hari di Wannsee dan melewati malam bersama di kediaman Alfred.

Pada tahun 1938, setelah gagal meraih penghargaan, Charlotte memutuskan untuk tidak lagi melanjutkan pendidikannya. Sementara itu, Alfred mulai seringkali menghilang dan tidak datang melatih vokal Paula, sehingga hal ini membuat Charlotte menghabiskan hari-harinya memikirkan pria itu. Tidak lama kemudian, ayah Charlotte dibawa oleh dua orang tentara Jerman untuk ditahan di kemah Nazi selama empat bulan.

"Berbaris di cuaca yang dingin, mereka menunggu berjam-jam. Beberapa orang sangat tua atau sangat lemah untuk bertahan. Mereka yang terjatub kemudian dipindabkan. Orang-orang tidak akan pernah lagi melihat mereka (hal. 136)."

Setelah dibebaskan dari kemah, ayahnya meminta Charlotte untuk meninggalkan Jerman dan tinggal di Prancis karena situasi yang semakin tidak menentu. Tetapi Charlotte menolak karena ia tidak mau berada jauh dari Alfred. Alfred yang mendengar cerita tersebut pun membujuk Charlotte untuk mengabulkan permintaan sang ayah.
"Mereka yang protes segera ditangkap. Mereka diseret hingga ke ujung kamp yang lain. Orangorang tidak lagi melihat mereka (hal. 136)".

Dengan berpegang teguh pada ideologinya anti-semitnya, Hitler bersama Nazi terus menerus menyerang kaum Yahudi yang tinggal di Jerman. Pemboikotan bisnis, penetapan aturan-aturan ketat, serta penghancuran bangunan-bangunan serta tempat ibadah, terus menghantui warga Yahudi.

"Tahun 1938 juga merupakan tabun kehancuran. Harapan terakhir Charlotte pun terbang ke langit (bal. 119)."

Ketika tiba di Prancis, Charlotte melihat harapan baru yang tidak ia miliki selama tinggal di negaranya akibat represi Nazi. Ia pun berharap bahwa penderitaannya selama di Jerman tidak akan lagi ia rasakan ketika ia tinggal di Prancis. Namun demikian, harapan Charlotte untuk terbebas dari Nazi pun harus pupus ketika rezim Vichy berkuasa dan Jerman mulai mengambil alih sebagian dari zona bebas di Prancis. Ketika itulah keselamatan Charlotte dan para pengungsi di Prancis mulai terancam.

"Perbatasan sangatlah mengkhawatirkan dan tertutup. Warga Jerman di Prancis diminta untuk melaporkan diri. Sangat jelas bahwa pernyataan itu untuk para pengungsi. Tidak peduli, mereka dianggap sebagai bangsa musuh. Pemerintab Prancis memutuskan untuk menyekap mereka (hal. 185-186).

Pada tahun 1940, Prancis menghentikan perang dengan Jerman di bawah rezim Vichy. Di bawah kepresidenan Maréchal Pétain, Pemerintah Prancis kemudian berkolaborasi dengan Jerman dan memulai penyekapan kaum Yahudi di Prancis untuk diasingkan di kemah Gurs. 
Nazi akan mengambil alih negara tempatnya melarikan diri. Negara para pengungsi di mana ia disekap. Tidak akan pernah ada akbir untuk pengembaraannya. Untungnya, penguasaan ini tidak mempedulikan bagian selatan. Orang-orang berbicara mengenai zona bebas. Tapi bebas untuk siapa? Tampaknya, tidak untuk dia (bal. 189).

Villefranche-sur-Mer yang terletak di daerah Selatan Prancis, Nice, seharusnya termasuk ke dalam wilayah zona bebas yang tidak diduduki Jerman. Namun Charlotte tidak benarbenar merasa tenang, ia masih merasa keamanannya akan terus terancam meskipun tinggal di daerah bebas. Kondisi neneknya sangat memprihatinkan. Wanita tua itu mengalami depresi berat, dan seorang dokter bernama Moridis tengah berupaya untuk menyembuhkannya. Karena keadaannya yang terus memburuk dan tidak dapat tertolong lagi, sang nenek memutuskan untuk mengakhiri nyawanya dengan bunuh diri. Tak berselang lama, kakek Charlotte pun meninggal dalam perjalanan menuju rumah sakit ketika merasa kondisi kesehatannya terus menurun.

Pada tahun 1940, pemerintahan Prancis menyekap sekitar 4.000 orang kaum Yahudi yang tinggal di Prancis ke kamp Gurs. Tempat ini merupakan milik pemerintah Prancis yang berlokasi di daerah Pirene, yang sebelumnya digunakan sebagai tempat pengungsian anggota partai politik dan Brigade Internasional yang melarikan diri dari Spanyol setelah Perang Saudara Spanyol. Namun ternyata, setelah genjatan senjata Prancis dengan Jerman, kamp Gurs kemudian diambil alih oleh rezim Vichy yang berkompromi dengan Nazi. Pada tahun 1942, wilayah Prancis Selatan diduduki oleh Italia dan Jerman. Wilayah yang diduduki oleh Italia, termasuk Villefranche-sur-Mer, seharusnya merupakan daerah yang aman dari pembantaian Nazi.

Pada masa persembunyiannya itu, Charlotte membuat sebuah karya autobiografi yang diberi judul Leben? Oder Theater? (La Vie? on Théâtre?) yang terinspirasi oleh kisah cintanya bersama Alfred. Sosok-sosok serta wajah-wajah yang ada digambarnya juga kata-kata dan potonganpotongan percakapan yang tidak akan pernah Charlotte lupakantercurah pada karya tersebut. Agar lukisan tersebut tidak jatuh ke tangan Nazi, ia kemudian menitipkannya kepada Moridis. Di l'Ermitage, Charlotte bertemu dengan seorang pria bernama Alexander, yang menemani Charlotte setelah kematian nenek dan kakeknya. Charlotte yang mengandung bayi Alexander pun memutuskan untuk menikahinya.

Pada tanggal 8 September 1943, Italia menyerah dan seluruh wilayah Prancis kemudian diduduki oleh Jerman. Sejak saat itulah, Charlotte mulai merasa sangat khawatir. Ia yang bersama Alexander, suaminya, berniat untuk melarikan diri, namun karena kondisi pria tersebut yang tidak sehat mereka akhirnya memutuskan untuk tetap bersembunyi di Villefranche-sur-Mer. Pada akhirnya dua orang tentara Jerman menjemput mereka dengan paksa untuk dideportasi ke kemah konsentrasi. Perjalanan menuju kemah konsentrasi sangat berat dan melelahkan, juga bagi Charlotte yang sedang hamil.

Orang-orang yang dideportasi tersebut akbirnya turun dari kereta. Lemah, lelah, lapar. Kabut 
pagi membuat mereka kesulitan mengenali kemah. Anjing-anjing yang menggonggong pun tak terlihat. Yang terlihat hanya sebuah tulisan di atas pintu gerbang. Arbeit Macht Frei. Bekerja Membawa Kebebasan (2014: 241).

Kemah konsentrasi Nazi digunakan untuk memfasilitasi rencana "solusi akhir" di beberapa negara Eropa yang dikuasai Hitler. Tempat-tempat tersebut dibangun dengan kuat agar efisien bagi mereka dalam melakukan pembantaian massal. Tergambar bahwa para korban Nazi yang dideportasi, diangkut dengan kereta api untuk kemudian diperkerjakan atau dibantai dalam kamar gas di kemah-kemah konsentrasi tersebut. Selama perjalanan pun, mereka dibiarkan lemah dan kelaparan oleh para penjaga, sebelum pada akhirnya dimusnahkan.

Pada gerbang kemah yang menjadi tempat pemberhentian terakhir Charlotte tersebut, terdapat sebuah tulisan bernada ironis dalam bahasa Jerman Arbeit Macht Frei yang berarti “Bekerja Membawa Kebebasan”.

Kekerasan mengontaminasi setiap hal. Di dalam barak, tidak ada kasur, hanya ada matras yang menumpuk. Kebersibannya sangatlah mengerikan. Setiap malam, mereka mendengar suara tikus yang berderit. Tikus-tikus itu menggerayangi pipi-pipi kurus para wanita (bal. 188).

Fasilitas yang diberikan kepada tahanan sangat tidak memadai dan kondisi kebersihan begitu buruk, sehingga para tahanan harus hidup dalam situasi yang sangat sulit. Hal tersebut menggambarkan penderitaan yang harus dipikul oleh kaum Yahudi atas kekejaman Nazi. Selain itu, bagi para tahanan wanita ada bahaya lain yang mengancam. "Setiap malam, ada pen- jaga masuk. Itu adalah ritualnya yang mengagumkan. Dia pergi untuk mencari seorang tahanan wanita untuk diperkosa (hal.188)." Beberapa perempuan juga ditangkap untuk menjalani penilaian fisik. Jika mereka cantik, mereka akan segera disterilkan. Mereka akan dikirim ke daerah timur sebagai pelacur untuk para prajurit Jerman (hal. 230).

Di gedung itu, mereka tahu bahwa mereka akan dimandikan. Sebelum masuk ke dalam bak, setiap orang menanggalkan pakaiannya. Mereka harus menggantung pakaian mereka pada rak baju. Seorang penjaga perempuan berteriak keras. "Selurubnya, ingat nomer rak baju kalian." Para wanita mengingat angka terakhir tersebut. Dan masuk ke dalam sebuah ruangan besar. Beberapa saling berpegangan. Ruangan dengan dua pintu tersebut kemudian dikunci, seperti di dalam sebuah penjara. Dinginnya cahaya es kemudian menusuk tubuh telanjang mereka. Charlotte terlihat dengan perut besarnya. Di antara yang lain, dia tidak bergerak. Dia nampak membebaskan dirinya saat itu (hal. 243-244).

Situasi yang digambarkan dalam sitasi tersebut merupakan prosesi pembantaian yang lazim dilakukan Nazi dalam kemah konsentrasi. Para tahanan diperintahkan untuk melepas pakaian dan mengingat nomor yang tertulis pada rak pakaian mereka, lalu diarahkan menuju sebuah ruangan besar yang terlihat seperti penjara dalam keadaan telanjang, sementara cuaca yang dingin menusuk tubuh mereka. Di ruangan tersebut, yang disebut dengan kamar gas, Nazi mengalirkan gas yang sangat beracun dan dapat membunuh korbannya dalam hitungan menit. Ketika itulah Charlotte meninggal bersama dengan bayi yang dikandungnya di dalam kemah konsentrasi.

Narasi dari Pencerita dengan Sudut Pandang 


\section{Terbatas}

Dari hasil bacaan secara heuristik, diketahui bahwa sudut pandang yang digunakan adalah kombinasi antara sudut pandang terbatas dan tidak terbatas. Sudut pandang tidak terbatas lebih dominan digunakan untuk menceritakan kisah hidup Charlotte dari masa kecil hingga saat tokoh ini meninggal. Karena sifat penceritaannya mahatahu, narator pertama ini dapat mengungkapkan isi hati Charlotte, ketakutannya, dan ia dapat berada di beberapa tempat dan waktu secara bersamaan.

Sedangkan sudut pandang terbatas digunakan narator 'Aku' yang beberapa kali muncul dalam cerita, khususnya pada bagian akhir novel. Ia mengungkapkan bagaimana dirinya menelusuri kehidupan Charlotte serta berkali-kali menyampaikan pemikiran pribadinya. Dalam narasinya, pengetahuannya terlihat terbatas, dan sering tampak ada kesan keraguan. Identitas narator pun terungkap di dalam cerita.

Christian Kolb, yang menerjemabkan novelnovelku ke dalam bahasa Jerman, bersama denganku. Dia butuh waktu sebelum berbicara. Dia selalu punya tiga poin kecil dari mulutnya. Aku memintanya untuk menjelaskan kedatangan kami. "Penulis Prancis... Charlotte Salomon...” (hal. 48).

Dari pernyataan tersebut dapat disimpulkan bahwa narator merupakan seorang penulis Prancis, yang telah memiliki banyak karya yang diterjemahkan ke dalam bahasa Jerman. Dalam hal ini dapat diasumsikan bahwa penulis yang dimaksud, yang menjadi narator ini adalah $\mathrm{Da}$ - vid Foenkinos sendiri. Dia sedang dalam perjalanannya menelusuri kehidupan tokoh Charlotte untuk kemudian diceritakan kembali kepada pembaca dalam bukunya. Dalam novel Charlotte ini, narator tersebut memang tampak tidak hidup sezaman dengan Charlotte, sehingga ia tidak mengenal tokoh wanita itu secara langsung. Narator ini mengumpulkan informasi mengenai tokoh utama melalui karya autobiografi yang ditulis sendiri oleh Charlotte maupun para saksi yang masih hidup yang pernah berinteraksi langsung dengan tokoh tersebut.

Suatu hari, aku masuk ke dalam sekolahnya. Gadis kecil itu berlari di dalam ruangan. Aku pikir bahwa Charlotte bisa saja berada di antara mereka. Di ruang sekretariat, aku disambut oleh penasibat pengajar. Perempuan yang ramah, namanya Gerlinde. Aku menjelaskan padanya alasan kedatanganku. Dia tidak tampak terkejut. Charlotte Salomon, ulangnya. Kami tahu siapa dia, tentu saja (2014: 36).

Dari sitasi tersebut, dapat diketahui bahwa narator menelusuri kehidupan Charlotte melalui kesaksian yang diberikan orang-orang yang pernah mengenal gadis itu. Narator juga mengunjungi sekolah Charlotte dan bertemu dengan seorang perempuan yang mengaku mengenal Charlotte.

Meskipun begitu, dia mempunyai seorang teman. Barbara, gadis cantik berambut pirang, kaum Arya yang sesungguhnya. "Aku sangat cantik, heil Hitler!" ucap Barbara. Setiap malam, mereka pulang bersama. Charlotte mendengarkan cerita-cerita temannya. Dia berbicara tentang kekasihnya. Hidupnya terlihat mengagumkan. Seandainya Charlotte bisa sedikit saja menjadi seperti Barbara (2014: 74).

Pada sitasi tersebut, terlihat penggunaan sudut pandang terbatas oleh narator yang menggambarkan kemungkinan pemikiran Charlotte 
mengenai ketidakadilan di antara dirinya sebagai orang Yahudi dengan teman Aryanya, Barbara. Dapat ditafsirkan bahwa Charlotte telah kehilangan kepercayaan dirinya, berbeda dengan temannya yang sangat ceria dan optimis menghadapi kehidupan. Menurut narator, situasi ini bisa jadi mendatangkan perasaan cemburu pada diri Charlotte.

Tidak sulit untuk berperan sebagai perempuan Arya yang baik hati. Pada hidup orang itu, semuanya mengagumkan. Sebuah dunia di mana tidak seorangpun meludahimu. Itu adalah dunia Barbara. Orang-orang menyukaimu, orang-orang membantumu, orang-orang memuliakanmu (hal.151-152).

Narator tampak menebak-nebak pemikiran Charlotte mengenai kehidupan yang dijalani Barbara. Ideologi yang ditanamkan mengenai keunggulan bangsa Arya memberikan keuntungan bagi kaum mereka di masa itu. Kehidupan yang mereka jalani merupakan kehidupan yang diidamkan kaum Yahudi, termasuk Charlotte. Bangsa Arya tidak perlu merasakan kebencian dan kemalangan yang mendera karena sebuah identitas yang dianggap tidak murni.

Beberapa hari begitu damai. Mereka mengingat masa depan. Charlotte menggambar lagi dan lagi, bermimpi untuk memasuki Fakultas Seni Modern. Dia terkadang berjalan hingga ke depan akademi itu. Dia melihat para murid yang keluar dengan karton sketsa mereka. Lalu, dia mendongakkan kepalanya. Sebuah bendera Nazi yang besar berkibar-kibar di bagian atas bangunan (bal.70).

Dalam sitasi tersebut, narator menunjukkan keputusasaan sekaligus ketakutan Charlotte melihat kekuatan tak terbatas Nazi yang tampak pada atribut-atribut yang terpasang di seluruh penjuru Jerman. Otoritas itulah yang telah merampas impian Charlotte untuk melanjutkan pendidikannya di Akademi Seni di Berlin. Melalui perasaan Charlotte tersebut, narator menggambarkan bahwa kekuasaan Nazi begitu besar tak terbendung sehingga kebebasan yang dimiliki kaum Yahudi pun terenggut.

Charlotte menetap di Berlin dengan ayahnya dan Paula. Dia kembali ke sekolah, di mana penghinaan tak terhentikan. Hingga tiba suatu ketika sebuah peraturan melarangnya untuk melanjutkan pendidikannya. Satu tahun sebelum wisuda, dia harus berhenti. Dia pergi dengan berita yang menunjukkan sebuah sikap sempurna (hal. 70).

Nazi telah merampas dan melanggar hakhak bagi kaum Yahudi melalui peraturanpertaruan yang ditetapkan, termasuk hak mendapatkan pendidikan yang layak bagi para pelajar Yahudi. Seperti diungkapkan pada pendahuluan, Nazi membatasi kuota bagi kaum Yahudi di setiap sekolah umum hingga 1\%. Setelah masuk sekolah dengan susah payah, Charlotte yang hampir menyelesaikan pendidikannya pun harus berhenti karena pelarangan tersebut.

Kegelisahan menyebar dengan cepat. Tidak mungkin bagi dia menerima penghargaan itu. Perayaan akan dibadiri banyak orang. Penilaian sekolah akan dibicarakan. Pemenangnya pun akan diumumkan. Dia sesegera mungkin akan menjadi sasaran. Dan akan membuatnya ditahan (bal. 120-121).

Charlotte harus merelakan penghargaan yang diberikan terhadap dirinya karena identitas Yahudinya. Jika ia tetap menerima penghargaan tersebut, ada kemungkinan pihak Nazi akan menangkapnya setelah pengumuman kemenangan. 
Melalui sitasi tersebut, narator memberikan penjelasan bahwa dengan berbagai cara Nazi tidak mau mengakui keberadaan kaum Yahudi sehingga mereka terus menyangkal serta melakukan diskriminasi kaum Yahudi yang berujung pada pemusnahan kaum tersebut.

Hari ini, orang-orang di perkumpulan diabadikan pada foto-foto itu. Mereka abadi, atau lebih tepatnya: tidak boleh dilupakan. Vila itu menjadi sebuah tempat penuh kenangan. Aku mengunjunginya di bawah matahari yang terik, di bulan Juni 2004. Kengerian dapat dilalui. Meja panjang di pertemuan tersebut sangat menyeramkan. Tempat yang ditimbuni oleh teror yang kekal. Begitulah, dingin yang merasuki punggung. Aku tidak pernah mengerti arti dari ekspresi tersebut sebelumnya. Wujud fisik dari sebuab sentuban yang dingin. Yang melintasi pilar punggung (2014: 113).

Dalam sitasi tersebut, narrator, sang penulis Prancis, mengungkapkan pemikiran pribadinya dengan menggunakan sudut pandang terbatas terhadap peristiwa nyata yang dialami Charlotte semasa hidupnya. Dalam narasinya, ia bermaksud mengingatkan pembaca terhadap penderitaan-penderitaan yang telah dialami Charlotte dan juga para korban kekejaman Nazi di masa lalu. Ia menyiratkan pesan kepada pembaca agar tidak melupakan peristiwa tersebut yang merupakan bagian dari sejarah, agar peristiwa serupa tidak terulang kembali di masa sekarang. Melalui pembahasan mengenai sudut pandang narrator ini, tampak jelas dampakdampak yang ditimbulkan akibat diskriminasi yang dilakukan oleh Nazi terhadap kehidupan yang dijalani tokoh utama maupun kaum Yahudi di setiap peristiwa-peristiwa yang terdapat pada novel yang dibahas.

\section{Kesimpulan}

Kasus diskriminasi, rasisme, dan Holocaust yang tergambar di dalam novel Charlotte memperlihatkan bagaimana manusia dapat melakukan sebuah kejahatan yang tidak terbayangkan pada sesamanya dengan berdasarkan pada fanatisme belaka. Dengan berakhirnya Perang Dunia Kedua dan kekuasaan Nazi ternyata tidak berarti fenomenafenomena diskriminasi serupa tidak lagi terjadi. Pada zaman modern ini, masih dapat ditemui kasus-kasus serupa meskipun tidak seberat dan seterbuka seperti sejarah kelam Holocaust yang dialami kaum Yahudi. Melalui pembacaan terhadap novel Charlotte, dapat dipahami bila pengarang berupaya mengingatkan pembaca terhadap hakhak azasi manusia. Sekalipun banyak sekali orang yang merasa pesimis dengan masa depan planet ini, Anne Frank (1929-1945), salah satu korban kekejaman Nazi, tetap percaya bahwa sesungguhnya apa yang dilakukan Nazi pada masa lalu bukanlah sebuah tindakan yang datang dari hati nurani manusia."Terlepas dari segalanya, aku tetap percaya bahwa orang-orang pada dasarnya sangat baik hatinya"-Anne Frank.

\section{Daftar Pustaka}

Barthes, R. 1991. Essais Critiques. Seuil. Paris

Berenbaum, M. 2016. Holocaust. https:// www.britannica.com/event/Holocaust, (diakses tanggal 12 Desember 2016, pukul 22.23 WIB)

Foenkinos, D. 2014. Charlotte. Folio. Paris

Fredrickson, George M. 2002. Racism: A Short Story. Princeton University Press. New Jersey. 
Goldenstein, Jean-Pierre. 1988. Pour Lire Le Roman. De Boeck. Paris

Hamon, P. 2014. 1991. La Description Littéraire. De l'Antiquité à Roland Barthes : Une Anthologie. Macula. Paris.

Hitler, A. 1925. Mein Kampf. Franz Eher Nachfolger. Berlin

Kumalasari, Isti. 2016. Membaca Gender dalam Konteks Post-Memory. Poetika : Jurnal Ilmu Sastra, IV (2), 61-63.

Schmitt, Michell-P \& Viala, A. 1982. Savoir Lire : Précis de lecture critique. Didier. Paris

Theodorson, George A \& Theodorson, Achillas G. 1979. A Modern Dictionary of Sociology. Barnes and Nobles Book. New York Sitografi .David Foenkinos.http://www.gala.fr/ stars_et_gotha/david_foenkinos

(diakses tanggal 5 November 2016, pukul 15.38 WIB) .Holocaust.https://www.ushmm.org/ wlc/id/article.php?ModuleId=10005143 (diakses tanggal 15 Oktober 2017, pukul 17.45 WIB) 